\title{
Leon Trotsky: Planet Without a Visa
}

\section{Bryan D. Palmer}

Multiculturalism, once perceived as a project of liberal-capitalist incorporation, is now all the radical rage, dressed in the new nomenclature garb of 'identity'. Pluralism, pilloried in the 1960 s precisely because it was judged a consensus ideology associated with the conformist politics of the 1950s, has taken on an almost sacrosanct stature in particular circles. Among those who embrace diversity as an answer to the ugly restrictions and repressions of various racisms and the coercive containment of policed gender roles, typecast sexual orientations, and a host of other institutionalised limitations, 'difference' is not just defended, it is extolled. There is much that is positive and humane in this. For this reason, perhaps, the left has been relatively slow to respond critically but fairly to the many issues raised by what might be congealed under the frameworks of multiculturalism/identity/diversity/difference. Of course much is at stake here, and matters are not always simple; nor are they simply what they seem through their designation.

Thus multiculturalism is a program of the contemporary liberal capitalist Canadian state, as well as an ethos that is embraced and lived in cosmopolitan urban centres. Identity can be a singular, essentialising label, applied to people mechanically, or it can be embraced as a layered set of subjectivities, complex in its multiplicities. Diversity and difference can be the basis for demands of inclusion or insistences on separation.

That said, notwithstanding its genuinely humane press that such difference should never be a foundation of exclusion, contempt, or restriction of basic rights, the multicultural program and demands of identity are prone to be assimilated within capitalist social relations. There is sufficient space for the privileged within the ranks of diversity, and various 'identities' can be incorporated, materially and ideologically, within capitalism's contemporary project. But the core relation of class exploitation, upon which inequality in our time rests, remains relatively unscathed by the politics and critique of advancing pluralism. And the deep, and economically orchestrated, continuities in special oppression that inevitably congeal class, race, gender, and other identities in ways that pay huge dividends for modern capitalism, are not so much transcended as massaged. The multicultural bandwagon, driven by the power of diversity/difference/identity, is thus as much of a 'myth' and a 'muddle' as it is an answer, at least from any rigorous left perspective. ${ }^{1}$

This is not to say, as some will want to pressure the discussion, that we must always fly the red flag of the primacy of class and the structured, objective economic base of all exploitation and oppression. No politics in our time can be forged on the basis of such a mechanical elevation. Rather, what con- 
sideration of multiculturalism/identity/diversity/difference demands is nothing less than an accounting that sees through the relentless one-sidedness of persistent claims to entitlement made in the name of this or that identity. For such one-dimensionality invariably elevates a specific component of humanity's oppression over many others. No identity, however influential, can ultimately trump the totality of identities, individually and collectively, that comprise the material and subjective experience of discontent that is the lot of the vast majority of the world's people and producers. If class is a central component in this materialized fusion of difference, it can never be separable from other components of identity, many of which have specific, discernible connection to articulations of material deprivation and dispossession.

It is instructive, then, to revisit, briefly and episodically, the life of one figure in the revolutionary past who both faced the stigmatizing antagonism of chauvinist thought, in particular anti-semitism, but refused political answers that did not strike out in universalizing opposition to all exploitations and oppressions. Leon Davidovich Trotsky, born Lev Bronstein, 26 October 1879, was most emphatically an object over his life of anti-semitic assault. Yet he constructed his appreciation of the need for 'permanent revolution' on the basis of a universalizing critique of capital and its rule. While Trotsky's writings recognized special oppression, he never elevated it above what he considered the wider and more fundamental 'laws' of accumulation, which insured the base of dispossession, alienation, and inequality without which capitalism could not sustain itself.

An archetypal 'non-Jewish Jew', in the sense outlined in Isaac Deutscher's essay of the same name, Trotsky always saw the 'national question' as subordinate to the necessity of global revolution. This must be led by the working class which, in the epoch of imperialist decay, was the only social force capable of constructing a true internationalism, within which all hope for humanity lay. Like his revolutionary counterparts, Karl Marx and Rosa Luxemburg or even Alexander Berkman and Emma Goldman, Trotsky found Jewry "too narrow, too archaic, too restricting." Such revolutionary Jews nevertheless had, in Deutscher's words, "something of the quintessence of Jewish life and of the Jewish intellect" as a central component of their subjective being.

They were a priori exceptional in that as Jews they dwelt on the borderlines of various civilizations, religions, and national cultures. They were born and brought up on the borderlines of various epochs. Their mind matured where the most diverse cultural influences crossed and fertilized each other. They lived in the margins or in the nooks and crannies of their respective nations. Each of them was in society and yet not in it, of it and yet not of it. It was this that enabled them 
to rise in thought above their societies, above their nations, above their times and generations, and to strike out mentally into wide new horizons and far into the future.

As revolutionaries these Jews lived the implosions of the bourgeois epoch, in which, as Marx's and Engels' words proclaimed, "All fixed, fast-frozen relationships, with their train of venerable ideas and opinions, are swept away, all new-formed ones become obsolete before they can ossify. All that is solid melts into air, all that is holy is profaned, and men at last are forced to face with sober senses the real conditions of their lives and their relations with their fellow men." The revolutionary Jew lived the seeming disintegration of Jewishness, indeed embraced it, seeking solutions to the crisis of humanity not by looking inward in spiritual confinement, but outward, to international society and its material expansiveness. This, of course, was the sin among sins conceived within the framework of all religions. And yet the revolutionary Jew remained Jewish, unable quite to escape certain fixed, fast-frozen relations, branded as that foreign other, "the rootless cosmopolitan." In the eyes of so many, a revolutionary Jew was often little more than very much the Jew. ${ }^{2}$

Trotsky was born at a moment of upheaval on the Russian land. Against the autocracy of the Czar and the stifling poverty of the peasantry, the Land and Freedom movement of 1879 fractured into two contending groups. The Freedom of the People wing placed the accent on civil liberties, while the Black Partition stressed the egalitarian distribution of rural property. In the months that Trotsky's mother endured her fifth pregnancy, carrying young Leon to term, Russian authority groaned under a series of terroristic attacks: a governor was shot; the chief of political police survived an assassination attempt; and on at least two occasions the Czar himself narrowly avoided death at the hands of those who would liberate the people through an act of political execution. Ruthless repression followed: mass arrests, deportations, hangings. This merely exacerbated the worsening situation, and in March 1881 the Czar was finally assassinated. Marx and Engels began to grasp the centrality of Russia in the revolutionary project, appreciating its pivotal place as a weak link in the reactionary chain of an ancien regime that reached across Europe from east to west, binding the oppressed masses of Russia, Germany, France, and England. In the preface to a Russian Edition of the Communist Manifesto, Marx noted that, "If the Russian Revolution becomes the signal for a proletarian revolution in the West, so that the two can supplement each other, then present Russian communal land ownership can serve as a point of departure for a communist development." Engels commented on the place of Russian developments as they related to the quickening pace of revolutionary agitation in Germany: "One thing we want is an immediate impact from without. It is the situation in Russia that will provide this for us."3 
The Russian upheaval did not come in the 1880 s, however, and the decade was one that Trotsky lived through as years of revolutionary defeat. The "best elements" of the agitations of the 1870 s "went up in the blaze of the dynamite warfare. The enemy had held all its positions. Then followed a decade of decline, of disenchantment and pessimism, of religious and moral searchings the eighties." Trotsky grew to intellectual maturity in these hard times, as the son of a farming family rising to prosperity, but still scraping to attain the material security that had not long in the past, seemed so illusive. The elder Bronstein had settled on a large farm on the southern Ukrainian steppe just prior to Trotsky's birth. He purchased 250 acres and leased a further 400 . Jews were not normally farmers in this period in Russia and were generally confined to the Pale, the towns that lay mostly in the western provinces annexed from Poland. But about 40 Jewish farming colonies had spilled out of the crowded ghettoes and on to the steppe bordering the Black Sea, part of a wave of immigrant Serbs, Bulgarians, and Greeks that colonized the uncultivated but fertile region in the early nineteenth century. David Bronstein was one of the few Jews to prosper sufficiently to break free of the Jewish colonies and establish himself privately on a fairly large tract of land. In doing so he was dubbed a 'lost' Jew by his co-religionists, an Am Haaretz characterized by his illiteracy and spiritual indifference. Only the moderate observation of Jewish rites by his more middle-class, urban wife tinged the Bronstein home with a patina of Jewish orthodoxy. The language spoken was not Yiddish, but a mixture of Russian and Ukrainian. In this milieu Trotsky spent the first decade of his life. ${ }^{4}$

Trotsky's autobiography, My Life, written as the leader of the Russian Revolution was driven from his homeland to a late 1920s exile on the island of Prinkipo, not far from the Turkish centre of Istanbul, constructs his youth in particular ways. They all tilt towards his later politics, but they do so in ways that are especially compatible with the revolutionary's sense of himself as a non-Jewish Jew. My Life is thus something both more and less than a statement of historical truth. Rather, it should be read as a chronicle illuminating later beliefs. The young Trotsky is made to appear in certain ways. Drawn less to the land and nature than he is to the mechanical skills of the local craftsman, Trotsky leans notably left but he does so in proletarian ways. This is a not surprising presentation of self given Trotsky's concept of permanent revolution, with the leading role of a working-class vanguard central to the project of creating and sustaining a socialist internationalism.

But more critical is Trotsky's supposed early antagonism to the relations of capitalist production and exchange in the countryside. The appetite for accumulation that consumed his youth and structured the family life of the Bronsteins is, for Trotsky, a deforming process, one that erodes the very essence of life, including the supposed happiness of childhood. While not poor, the Bronsteins were wanting in richness of vision because they were con- 
strained by their quest for money and the possibilities it offered in terms of profit, if not power.

My childhood was not one of hunger and cold. My family had already achieved a competence at the time of my birth. But it was the stern competence of people still rising from poverty and having no desire to stop half-way. Every muscle was strained, every thought set on work and savings. Such a domestic routine left but a modest place for the children. We knew no need but neither did we know the generosities of life - its caresses. My childhood does not appear to me like a sunny meadow, as it does the small minority; neither does it appear like a dark cave of hunger, violence, and misery, as it does to the majority. Mine was the grayish childhood of a lower-middle class family, spent in a village in an obscure corner where nature is wide, and manners, views and interests are pinched and narrow.

This assessment of Trotsky's formative years drifts perceptibly towards the human face of socialism, the young Russian rebel apparently quick to identify with the oppressed masses. Trotsky was, for instance supposedly often upset at the harsh disciplinary treatment his father meted out to the local peasants or the sparse dietary provisioning the elder Bronstein allowed his agricultural labourers. In a mythology of the seven-year old Trotsky, Max Eastman perhaps captures the canonization most succinctly: "His sympathies were belligerent. His tenderness was rebellion." Encountering a peasant woman, barefoot at his father's door, awaiting payment of a cherished single rouble, Trotsky recalled: "It made my heart tighten to look at that figure - the embodiment of poverty and submission." Lounging about the blacksmith's fire, Trotsky claimed to have heard stories of the local scene that put his relatively well-off father in a light that he did not see him in around the family hearth. "Propriety did not always rule there," according to the young Bronstein, who concluded that, "My horizon was widened hourly," by the uncomplimentary stories the workmen told of the elite. This class sensibility soon blurred into a cultured antagonism to the crudeness of rural life: "The country brought me face to face with the various types of decadence in the gentry, and the types of capitalist aggrandizement. It revealed to me the natural coarseness of many aspects of human relationships, and intensified my feeling for that other type of urban culture, at once advanced and more contradictory." 5

Trotsky understandably harboured increasingly ambivalent feelings toward his father. Appreciating his keen judgements of human character, his perseverance, and the shared bond of labour that linked the elder Brontstein and his wife, Trotsky also apparently grew up chagrined at his father's parsimonious, 
exacting nature. "By indefatigable, cruel toil that spared neither himself nor others, and by hoarding every penny," he wrote, "my father rose in the world." The son, inundated by a European anti-semitism that identified Jews with trade and jobbing, money lending and money making, came to see his father as the stereotypical 'driver of hard bargains'. Trotsky paints his father in the colour of money's meanness: "My father never made a mistake in what he bought: cloth, hats, shoes, horses or machinery, he always got his money's worth." Nothing mattered, "but the price of grain in the world market." Embarrassed by his father's stinginess, Trotsky claimed that his future freeness with money was a product of his upbringing, "a reaction against the closeness at home." "I lived in a petty bourgeois environment," Trotsky explained, "where the principal effort was directed toward acquisition. ... The petty bourgeois outlook and habits of life - from these I sailed away with a mighty push." Years later, driven into exile, Trotsky was described by one of his guards: "Trotsky never had any money on him. He lived in countries without ever knowing the colour of their bills." Trotsky assimilated the revolutionary repudiation of capitalism with a rejection of its caricatured Jewishness.

This is also evident in Trotsky's virtual denial of Jewish oppression in late nineteenth-century Russia. His opening chapters of My Life, as Hans Mayer points out in an irascible account, "Comrade Shylock," are set in an almost entirely Jewish milieu. Yet they have almost nothing to say about the tightening knot of anti-semitism on the Ukrainian steppe or in its major city, Odessa, where Trotsky would, in the 1890 s, be educated. Trotsky bypasses the 1881 edicts that terminated his father's right as a Jew to buy land because, ostensibly, the restrictive laws were of little importance: his father, now growing richer, was able to lease acreage from the declining Ukrainian aristocracy. He makes little of the 1887 ukase that limited Jews to between three and ten percent of the pupils in secondary schools, Jewish students being forced to sit competitive examinations in order to secure one of the favoured entrance passes. Because his family was able to pay for his training for a year, to upgrade Trotsky's status after failing the first-round examinations, Trotsky eventually did gain admittance to an academy. There, if we are to believe the account in My Life, remarkably little discrimination could be detected. Money trumped oppression; Jewishness, and its prices, were bartered away when the purse was full. $^{7}$

For Trotsky, the limitations of the rural Ukraine were overcome by books, and his love of reading and study developed alongside a rather prim fastidiousness. Schooled in Odessa, one of the most police-ridden cities in Russia, the young Trotsky was at first oblivious to the politics of rebellion. He was, to be sure, expelled from school for supposedly leading a boyish prank directed at an unpopular teacher, but was allowed to re-enter and was, throughout his seven years of education, a first-class student. Gradually the young Bronstein came 
to loathe the country and revere the town, going so far as to equate his scholarly orientations to urban culture and its oppositional challenges to the narrow empiricism of rural knowledge. Bronstein was giving birth to Trotsky, as this search for generalization and historical laws of development planted a seed that Trotsky later claimed was the origin of his "philosophic outlook on life."

The feeling of the supremacy of general over particular, of law over fact, of theory over personal experience, took root in my mind at an early age and gained increasing strength as the years advanced. It was the town that played the major role in shaping this feeling ....... The dull empiricism,the unashamed, cringing worship of the fact which is so often imaginary, and falsely interpreted at that, were odious to me. Beyond the facts, I looked for laws.... The social-revolutionary radicalism which has become the permanent pivot of my whole inner life grew out of this intellectual enmity toward the striving for petty ends, toward out-and-out pragmatism, and toward all that is ideologically without form and theoretically ungeneralized. ${ }^{8}$

Trotsky's animus toward his father's monied limitations was taking on the trappings of a nascent world-view.

Eventually the young Bronstein's "subconscious strivings" against arbitrary authority, czarist hierarchical power, and the unjust conditions the people were forced to endure, crystallized in a romanticized version of advanced European civilization. Under the pressures of marxism, historical materialism, and the rise of a new wave of populist-socialist agitation, this perspective began, in 1896, to take on new, more forcefully oppositional, direction. Finishing his education in the provincial town of Nikolayev, Trotsky encountered for the first time the stimulations of critical, radical thinking. He was particularly taken with the leading figure of German socialism, Ferdinand Lasalle, and became involved with a cohort of idealistic youth who struck out in a range of populist causes. Soon they were smuggling revolutionary literature into the town. Through contact with workers, Trotsky and others formed a South Russian. Workers' Union that eventually led to Trotsky's first stint in jail, an incarceration of 18 months. He was 19 years of age. The czarist prison proved a nursery of revolutionary practice. Bronstein read vociferously, first devouring Lenin's recently published book on The Development of Capitalism in Russia behind prison walls. Edward Bernstein's The Premises of Socialism passed clandestinely from cell to cell, where it generated fierce debate among the seasoned revolutionaries with whom the young Jewish exile from the Ukrainian steppe now rubbed shoulders. Trotsky led protests in prison, and, in a refusal of patriarchal privilege, insisted on doing his own laundry and mend- 
ing his own clothes, generally a task allocated to wives and girlfriends of political prisoners.

It was behind bars that Trotsky married his first wife, the Narodnik, Alexandra Sokolovskaya. A Jewish chaplain conducted the wedding that his father had at first refused to sanction for his underage and now clearly wayward son. The new couple found freedom of a sort in 1900, being exiled to Siberia, where Trotsky worked as an accountant by day and brushed cockroaches off the pages of Das Kapital at night. He and Alexandra had two daughters in the cold and barren village of Verkholensk, just below the Arctic Circle, living in a small two-storey house that was subject each night to an unannounced visit by the police inspector.

Among the revolutionaries pushed to the margins of Russian society there now developed large and contentious debates. Trotsky was often at their centre: marxism vs subjectivism; socialism vs anarchism; mass struggle vs terrorism. The timelessness of the subjects is well known to all on the revolutionary left. But Trotsky was also cultivating an uncharacteristically wide revolutionary aesthetic, situating Nietzsche within the writings of Herbert Spencer and offering an expansive literary criticism that encompassed Ibsen, Shakespeare, and Darwin, as well as classic Russian authors. ${ }^{9}$ Prison and exile not only nurtured Trotsky's development as a revolutionary. Ironically, in its parochialism and containments, it sustained his cosmopolitanism and completed his selfeducation as a marxist. It also confirmed Trotsky as the non-Jewish Jew, Jews being outlawed in Siberia except as political prisoners and condemned exiles. When Bronstein needed to secure a false passport to make his escape from Siberia to join the growing Russian Revolutionary Social Democratic movement, he took the name Leon Trotsky. Supposedly neutral, it was a noncommital identification that, for once, obliterated the otherness of race/religion. It had been the name of his prison warden at Odessa. ${ }^{10}$

The exile community in Siberia developed its own society, political, cultural, and institutional. Trotsky lectured, debated, polemicised, and wrote, steeling his self-confidence for the wider struggle that both he and his wife agreed would someday take him away from exile. In the summer of 1902 the underground mail system brought Trotsky Lenin's pamphlet, What Is To Be Done? and a package of the new revolutionary newspaper, Iskra. Lenin and the émigré revolutionaries who had fled Russia to establish citadels of propaganda and theory in Geneva, London, and Munich, were coming to the same conclusions about the necessity of a disciplined party apparatus that Trotsky was himself working towards in the grey mud and cramped cobblestoned streets of a Siberian village. Eventually word came that Trotsky must escape exile and join the Iskra group abroad. He was smuggled out of Siberia by a peasant. The revolutionary on the run was helped across the Russian border by a terrorist irate that Trotsky was going to join forces with theoretical marxists who were attack- 
ing the politics of violent retribution as a means to liberation. Stumbling from Vienna to Zurich to Paris to London, Trotsky expended his allocated financial resources with a liberal generosity to porters and aids. His pockets were soon empty and his clandestine hosts exasperated. Trotsky eventually found his way to Lenin's door. His nom-de-guerre was Pero, 'The Pen', a tribute to his success as an underground journalist in Siberia. ${ }^{11}$

Trotsky was now separated from his wife Alexandra, on whom was imposed a second term of exile. His relations with his original, farming family were strained to the point of limited communication. The non-Jewish Jew was living the legend of the Wandering Jew. This anti-semitic literary motif was associated with international Jewry in the nineteenth century, but was developed with more positive political poignancy in Eugene Sue's 1844-1845 left-wing novel, The Wandering Jew, first published in Paris. In its origins the legend of the wandering Jew rested on the personification of the Jewish people in Ahasuerus, a Jerusalem man who supposedly accosted Christ for pausing on his doorstep as he carried his Cross to Calvary. Admonishing Christ to 'Walk faster' and move away from his home, Ahasuerus was ostensibly told by Christ, "I will go, but you will walk until I come again." Thus the Wandering Jew is, in the lore of anti-semitic Christian condemnation, a figure of deserving alienation. He is destined to a suffering of walking homelessness that, metaphorically, locates rootless Jewry, without national homeland, in an original diasporic sin. Sue's book adds a political dimension and more positive reading of this legendary construction, seeing the Wandering Jew as a champion of the oppressed, struggling in his migrations against "the rich, the idle, the arrogant." Thus composed of complex congealments of anti-semitic thought and proJewish, progressive sentiments, the legend of the Wandering Jew consolidated in European folklore and literature after 1850. It took on different trappings and could, of course, in the culture of specific nation states such as Germany in the unification era, tilt decidedly in a xenophobic, anti-semitic direction. In other contexts, its meanings were different. Its varied strains seem realized in the life of Trotsky, a man who, having made himself into a Revolutionist, was condemned to exile in his homeland.

Trotsky as the Wandering Jew gave his life to the making of that Revolution, only to be driven to cross Europe, even to touch down in North America, to secure his ends. Finally, having made a Revolution, Trotsky was then forced to leave the revolutionary state he had helped to create. Few spaces on the globe were open to his need for asylum. Trotsky was thus a man caricatured as a Jew and a revolutionist by elements of the right and the left alike; a man eventually marginalized in Mexico where, his wanderings having come to a stop, he was eventually killed by an assassin sent by the degenerating workers' state Trotsky had himself done so much to bring into its original, world-historic being. 
When we add to this Trotsky's commitment to cosmopolitan culture contrasted with Stalin's crude national chauvinism, further parallels appear. Trotsky's weapon of the word and his evolving programmatic orientation toward permanent revolution stood in stark contrast to Stalin's consolidation of socialism in one country, a politics secured through authoritarian control and decimation of an entire layer of revolutionary leadership. It is not difficult to see in Trotsky's life, then, a parallel with the legendary plight of the Jews, a people constructed as dedicated to ideas and caricatured as manipulative brokers in the nationless world of money. Refused the comfort of a homeland, Jews were driven to desperation by a history of exclusion and violent assault, reaching from the pogroms of Poland to the holocaust. ${ }^{12}$

Prior to the 1917 Revolution, Trotsky was regarded with a mixture of antiintellectualism and anti-semitism by moderate critics on the reform left and agents of the European states alike. As Trotsky penned articles in Austria in 1914 , his name was brought to the attention of the state's foreign minister, who was warned that with the outbreak of war foreign revolutionaries might well foment revolutionary agitations. "I beg your pardon," snorted the officious guardian of power, "Who here is going to make a revolution? Mr Trotsky, perhaps, from the Cafe Central?" The Belgian social democrat, Henri de Man, was equally contemptuous. He thought Trotsky nothing more than a man who "spent half the day reading and writing and half the night ... carrying on discussions in a cafe full of literati ... a bohemian piano virtuoso [with] an uncontrolled nervousness ... belong[ing] to a certain type of artist." As a leader of the Red Army, de Man regarded Trotsky merely a "propaganda bluff." History has had the last word on a de Man/Trotsky comparison. De Man, true to the colours of the Second International, aligned himself with his government during World War I, abandoning the principles of proletarian internationalism that Trotsky and Lenin held as a touchstone of the revolutionary tradition. When Trotsky travelled by train to Petrograd in 1917 he met de Man, who asked, solicitously, if he remembered the Belgian socialist. Trotsky replied appropriately: "I do," he said, adding with insight, "although people change a lot in time of war." (How we have come to appreciate such malleability in our times!) $\mathrm{He}$ would not have been surprised at de Man's World War II collaboration with the Nazis. To de Man, writing contemptuously of Trotsky in 1953, when it was apparent to all what Trotsky had sacrificed for principle and revolutionary internationalism, a Jewish bohemian could not be a true revolutionary. Who, it might be asked of de Man and so many other apostate socialists, could fulfill the task, if not a man of ideas willing to act. ${ }^{13}$ The non-Jewish Jew, it seems, could not quite escape the 'fact' of his Jewishness.

This is confirmed even at the high point of Trotsky's revolutionary accomplishment. On one level, Trotsky's wanderings ended only with the redemption of Revolution. The only period of his life when he was not forced into exile, 
both metaphoric and real, was associated with Trotsky's leadership of the Red Army, the victorious creation of the first workers' state in 1917, and his stature as People's Commissar of Foreign Affairs and, later, Commissar of War and Defense. The mid-sections of My Life, covering the years of his escape from Siberia to his arrival in Petrograd in May 1917, at which point he assumed, next to Lenin, the unambiguous role of pre-eminent agitator, theoretician, and leader of the revolutionary movement, highlight the importance of mobility in Trotsky's life. They bear chapter titles indicative of the experiences of a man driven from geographic pillar-to-post in an unsettled and unsettling activism: 'Trial, Exile, and Escape'; 'My Second Foreign Exile: German Socialism'; 'Preparing for a New Revolution'; 'The Beginning of the War'; 'Paris and Zimmerwald'; 'My Expulsion from France'; 'Through Spain'; 'New York'; and 'In a Concentration Camp' [a Canadian sojourn in Amherst, Nova Scotia].

Much could be written on these years. Debates raged between Mensheviks and Bolsheviks, in which Trotsky sided originally with the former against the latter and Lenin. Trotsky's historic leadership of the Petrograd Soviet in 1905 was a pivotal turning point in a revolutionary life. Conceptually, Trotsky's years of movement also gave rise to the evolving theory of permanent revolution. All of this was not unrelated to Trotsky's changing personal circumstances, in which he consolidated a life-long comradeship with Natalia Ivanova Siedova, mother of his sons. The central point is that these were years of largely rootless engagement with the revolutionary cause, of heroic struggle often followed by defeat, exile and marginalisation. Yet such years, as well, saw the sinking of deep roots in the concrete attempt to forge a new world. In the making of the first foundational achievement of working-class power in that world-to-be between 1917-1921, Trotsky achieved an end to his wanderings. It was a political convergence in which the oppressed masses, the splendour and power of transformative ideas, and the making of history came together in the work of revolution, a recharting of the very understanding of 'nation':

In the life of the country and in the life of the individual, these were extraordinary days. ... The masses were creating an epoch and their leaders felt their steps merging with those of history. On the decisions made and the orders given in those days depended the fate of the nation for an entire historical epoch. ... The hidden strength of the organism, its most deeply rooted instincts ... rose and broke through the psychic routine to join forces with the higher historico-philosophical abstractions in the service of the revolution. Both these processes, affecting the individual and the mass, were based on the union of the conscious with the unconscious; the union of instinct - the mainspring of the will - with the higher theories of thought. ${ }^{14}$ 
In power, Trotsky remained very much this man of transformative potential, his revolutionary sensibilities always attuned, perhaps overly so, to the problematic realities willed to the revolutionary leadership from a past more constrained by varied limitations. Trotsky would have preferred the literary limelight, avoiding positions of authority that fell inevitably to him to fulfill. With the Bolshevik ascent to governance, he offered to undertake the work of the revolutionary press, feeling the need, after the intensity of the months of mobilization, for rest and a teturn to the power of words and the persuasions of argument as opposed to the appeal to arms. But Bukharin was assigned to that task, and Lenin pushed for Trotsky to assume the pivotal post of Commissar of the Interior. There Trotsky would be responsible for the security apparatus of the new workers' state, a charge of pivotal importance given the likelihood of counter-revolutionary organization. Trotsky argued against such an appointment. In the ensuing discussion he angered Lenin with allusion to the ways in which his Jewish origin would be used against the head of security, enemies of the Revolution being given a made-to-order weapon with which to appeal to the anti-semitism still thriving in Russia. "We are having a great international revolution," replied Lenin hotly, "Of what importance are such trifles." Trotsky responded good-naturedly: "No doubt the revolution is great. But there are still a good many fools left. ... Why create additional complications at the outset?" Losing the argument, Lenin shrugged his shoulders in resignation and Trotsky was given the seemingly less important post of Foreign Affairs. Trotsky's analytic recollection, years later, placed the accent on how unaffected he personally was by a politics of identity:

I have already had occasion to observe that the national question, so important in the life of Russia, had practically no personal significance for me. Even in my early youth, the national bias and national prejudices had only bewildered my sense of reason, in some cases stirring in me nothing but disdain and even a moral nausea. My Marxist education deepened this feeling, and changed my attitude to that of an active internationalism. My life in so many countries, my acquaintance with so many different languages, political systems and cultures only helped me absorb that internationalism into my very flesh and blood. ${ }^{15}$

Yet, as his arguments against taking on the portfolio of Commission of the Interior suggest, Trotsky was not unaware of the political passions identity could arouse.

As Trotsky summoned the national question to take him out of the public eye, a supreme irony capped the Bolsheviks' decision on who to appoint to the Commissar of Nationalities: Joseph Stalin. His equivocations on anti-semitism 
kept in check by Lenin and others in 1917, Stalin would later descend directly into the depths of racial caricature in his orchestrated assault on Trotsky and the Left Opposition in the later 1920s. Most viciously, in a later chapter of the book of terror waged against the Old Bolsheviks in the Great Purge Trials of 1936-1938, Trotsky, Zinoviev, Kamenev, and Radek, all Jews, were repeatedly slandered as 'people without a fatherland', creatures devoid of native Russian feeling. When Trotsky attempted to address the degeneration of the Revolution under Stalin in the early 1920s, his talks before Party cells in Moscow were met with ugly allusions to his Jewish origin and even overt anti-semitic insult. Trotsky responded in shocked surprise that Stalin would sanction such unBolshevik, non-socialist innuendo and invective. Having spent his revolutionary life denying the necessity of anything smacking of Jewish cultural autonomy, the better to build, in his visionary perspective, a socialist solidarity of Jew and non-Jew, Trotsky could understand arguments over program within the Soviet Union in the mid-1920s. He may even have expected the worst from Stalin on this front, but he simply failed to anticipate, even to fathom, the resort to national chauvinism and racism within the revolutionary ranks.

After Trotsky's murder in Mexico, Stalin's corruptions on this score would mount. They included overt refusal to confront the Nazi project of Jewish extermination, not just during the notorious Hitler-Stalin pact of 1939-1941, but more menacingly after knowledge of Auschwitz and the program of a 'Final Solution' was widespread. Stalin's tortuous practice of expediency, in which he backed away from acknowledgment of the holocaust in order not to fan the flames of anti-semitic antagonism within the Soviet Union, extended to absolute silence on the extermination of 60,000 Jews by German occupiers in the Kiev city of Babyi Yar. In the post-war period, Stalin waged a war against the right of Jews to sustain their secular culture and, under the banner of assimilation, effectively outlawed Jewish theatres, publications, and almost all venues of institutional life. Writers, poets, and actors, not to mention old guard Bolshevik activists in the anti-fascist movements of the European left, such as Lozovsky, one-time head of the Red International of Labor Unions, were subjected to the terror of imprisonment, trial, and execution. The secret police unleashed a repressive sweep that left many Jewish cultural figures 'disappeared'. In the Soviet press, attacks on "rootless cosmopolitans" and people of "uncertain allegiance" abounded, and there were rumours that all Jews in the Soviet Union were to be deported to the Jewish Autonomous Region of Birobidjan. When, in 1953, the supposed 'Doctors Plot' was uncovered, nine professors of medicine serving the Kremlin elite as personal physicians ostensibly being unmasked as agents of foreign capitalist powers intent on bringing the Soviet Union to its knees, the Stalinist utilization of anti-semitism reached new lows. Most of the so-called "assassins in white blouses" were Jews, and all were roundly denounced as part of an international conspiracy aimed at 
Stalin's power, identified as part of a New York-based clandestine cell known as 'the Joint'. It was now almost too much for even the accommodated hand-raisers surrounding Stalin to stomach, and as newspapers spilled out a gutter-like effluvia of anti-semitic attack, Stalin himself personally orchestrated the repression of the house doctors. Charges and formal trials were dispensed with. Stalin supervised the interrogations of the accused, ordering them to be chained and beaten, and advising his Minister of State Security to secure speedy admissions of guilt: "If you do not obtain confessions from them," Khruschev later reported hearing Stalin dictate, "we will shorten you by a head." 16

1953 was a long way from 1917, and Trotsky, of course, was dead, the victim of Stalinist assassination. The cultured revolutionary had lost the battle against Stalin for control over the direction of the Russian Revolution by the mid-1920s, his January 1925 dismissal from the post of Commissar of War and Defense being a decisive indication of how he was now deposed. He fought on, valiantly, but the prophet, in Deutsher's metaphor was now unarmed. In the cause of revolution, a lack of arms is the end. Still, from 1921-1929, Trotsky battled without concession, challenging the drift away from socialist internationalism evident in Stalin's evolving ideology of socialism in one country, a pragmatic politics of counter-revolution that saw Stalin himself enshrined as 'the Great Organizer of Defeat'. The bitter tastes of this were felt in the Communist International's contribution to the crushing of the British General Strike in 1926 and the Chinese Revolution in 1926-1927. Stalinist erosions of essential Leninist understandings of revolutionary strategy, in which alliances with bourgeois nationalists and peasant rebels replaced the united front tactics of a politics of class struggle, drew Trotsky's particular derision. In these years Trotsky returned to aesthetics, penning his classic statement on Literature and Revolution in 1924. But he also developed, in articles and speeches and the organisation of a Left Opposition, the foundations of major theoretical texts on the Russian Revolution and its degeneration, including his 1924 homage to Lenin, his opening salvo against Stalinism in the 1923 volume, The New Course, and his subsequently published The Permanent Revolution (1930) and The Revolution Betrayed (1936). ${ }^{17}$

For many, the "rootless cosmopolitan," the "cafe socialist," had failed in the political contest of an iron law of oligarchies. The bohemian was no match for the ruthless machiavellian. There was more to the Stalin-Trotsky opposition than that, of course, and a part of the answer of Trotsky's defeat lay less in the character of his 'man of letters' stature than in the determining materialist circumstances that pitted a capitalist world of containment and encirclement against international revolutionary initiatives. Trotsky, of all people, understood these to be dependent on the explosive capacities of the world proletariat. Those capacities were harnessed and subordinated, and their liberatory 
potential never realized. The defeat of the German Revolution of 1923 was decisive, the ultimate price being paid, a decade and a half later, by six million Jews.

Whatever the reasons for Stalin's victory and Trotsky's defeat, in 1928 it registered in Trotsky's final exile. Expelled from the Bolshevik Party he had helped to lead to power in 1917, Trotsky was placed under G.P.U. guard and transported again to Siberia. His final destination was Alma-Alta on the Chinese-Russian border, an outpost of isolation as grim as any Trotsky had faced under czarist repression, and one complicated in physical danger by earthquakes and floods. After a year, Trotsky, even in far off Alma-Alta considered by Stalin a threat, was determined too dangerous a presence to the Soviet Union to reside within its borders. Ordered to be deported, no country would at first take him. After a fortnight of negotiations, the Stalinist state secured Trotsky's passage to Turkey, where he was to live under strict conditions of political constraint. Confined largely to the island of Prinkipo, Trotsky was allowed to travel out of the country once, invited by Danish socialist students to address them in Copenhagen in 1932.

Small bands of Trotskyist followers, struggling to build an organized International, made the trek to Turkey to engage in dialogues with a leader now known as 'the Old Man'. They found Trotsky open to varieties of discussion, working on his magnum opus, a three-volume History of the Russian Revolution that, upon its publication in the early 1930s, quickly gained the stature of a major literary accomplishment in narrative and analytic history. Now a lover of nature, Trotsky enjoyed going out to harvest the seas with Turkish fishermen. But the revolutionary was at this time truly rootless, his home always subject to harassment and the threat of Stalinist attack. By 1932, with Trotsky putting out a Bulletin of the Opposition in Russia, and Stalin about to embark on a final decisive purge of any who might challenge him, Trotsky, after much pressure on his behalf, secured the right to move to Paris. Trotsky and his entourage were in France for only a brief time before the authorities forced a move to Norway, which, in turn, would eventually find him an unwanted citizen. Shunted from one European nation to another, denied access to so many others, Trotsky was a truly marginalized 'other' shunned for his singular identity as one of the world's most dangerous revolutionary internationalist. Mexico would eventually be his final asylum, but this respite lasted only a few years before Stalinism silenced his revolutionary pen by burying an ice pick in his brain. ${ }^{18}$ His last polemical writing, In Defense of Marxism, published posthumously in 1942, defended the legacy of the Russian Revolution. It insisted that in a contest between war, imperialism, and the degenerated workers' state, the revolutionary left must be vigilant in maintaining its critical support for the Soviet Union. ${ }^{19}$

Trotsky refused all notions of personalizing his oppression, of assuming 
the mantle of some kind of victimisation. "Since my exile I have more than once read musings in the newspapers on the subject of the 'tragedy' that has befallen me. I know no personal tragedy," he thundered. The political lessons were never lost sight of by Trotsky, who abstracted his subjective position into an analytic orientation that highlighted, not simply the evils of revolution's deformations, but the larger crisis of humanity that was everywhere evident in the contradictory hypocrisies of capitalist globalization:

Europe and America without a visa. But these two continents own the other three. This means - the planet without a visa. On many sides it has been explained to me that my disbelief in democracy is my greatest $\sin . .$. But when I ask to be given a brief object-lesson in democracy, there are no volunteers. The planet proves to be without a visa. Why should I believe that the much more important question - the trial between the rich and the poor - will be decided with strict observance of the forms and rituals of democracy? ${ }^{20}$

Like many of Trotsky's words, these resonate through the ages.

Trotsky was not the first to choose internationalism over identity and universalism over particularity, but he deepened the tradition of revolutionary refusals of all parochialism. He lived globalization in ways that its current corporate advocates could never imagine, raising always the banner of universal human emancipation. Against imperialist markets and their ideologies, he proclaimed the necessity of a communist cooperation whose ultimate realization lay in the possibility of a utopian future, but whose present practice could begin to erode the debilitating anachronism of acquisitive individualism. Against the deforming project of socialism in one country he articulated a program of permanent revolution. Against the varied exploitations and oppressions so evident throughout a twentieth century of capitalist 'progress' marked by war, genocide, widening immiseration, and expanding circles of debasement, Trotsky insisted on the liberating possibility of a radical social transformation. In words and in deeds, and with his own life, in the end, he lived this active endeavour. Today, his ideas and his example are with us all, regardless of our 'identities'. This, then, was no embrace of pluralism, multiculturalism, and the reification of identity's difference. Rather than opt for a politics of particularity, Trotsky gravitated unerringly in the direction of a politics of universality, orchestrated by the foundational materialities of class power but never reduced to a crude oppositional economism.

The experience of Trotsky, then, is worth contemplating in these times of identity's vitalities and imperialism's powerful, and increasingly destructive, revival. Our planet is being declared free and open, but there are no visas for humanity. In the project of bringing a revolutionary left back into being, the 
significance of ideas accenting the need to stamp humanity's visas, not with the names of difference, but with the authority of universal commonalities shared by all peoples who suffer because of the varied degradations nurtured at the accumulative breast of capitalist need, and those who embrace the cause of their freedom, will figure forcefully. The recovery of Trotsky's legacy, then, is something of a passport to the possibilities of a renewed left politics of opposition to late capitalism's 'new world order', and its marauding campaigns of conquest and annihilation.

\section{Notes}

${ }^{1}$ For critical comment on multiculturalism see Russell Jacoby, The End of Utopia: Politics and Culture in an Age of Apathy (New York: Basic Books, 1999), 29-66; Brian Barry, "Muddles of Multiculturalism," New Left Review 8 (March/April 2001), 49-72.

${ }^{2}$ This paragraph draws upon Isaac Deutscher, "The non-Jewish Jew," in The Non-Jewish Jew and other essays (London: Oxford University Press, 1968), 25-41; Marshall Berman, All That Is Solid Melts Into Air: The Experience of Modernity (New York: Simon and Schuster, 1982), 87-129, esp. 95.

${ }^{3}$ See Haruki Wada, "Marx and Revolutionary Russia," in Late Marx and the Russian Road: Marx and 'the Peripheries of Capitalism', ed. Teodor Shanin (New York: Monthly Review Press, 1983), 40-76.

${ }^{4}$ Isaac Deutscher, The Prophet Armed: Trotsky, 1879-1921 (New York: Vintage, 1965), 6-11; Leon Trotsky, My Life (New York: Pathfinder, 1973), 1-40, 93.

${ }^{5}$ Trotsky, My Life, 1, 21-22, 25-26, 78, 81; Max Eastman, Leon Trotsky: The Portrait of a Youth (New York: Greenberg, 1925), 8-10, 12.

${ }^{6}$ Trotsky, My Life, 6, 16, 18; Jean van Heijenoot, With Trotsky in Exile: From Prinkipo to Coyoacan (Cambridge: Harvard University Press, 1978), 72.

${ }^{7}$ See Hans Mayer, "Comrade Shylock," in Outsiders: A Study of Life and Letters (Cambridge: MIT Press, 1982), 369.

${ }^{8}$ Trotsky, My Life, 87-88.

${ }^{9} \mathrm{See}$, for a succinct overview of this period, Deutscher, Prophet Armed, 22-55.

${ }^{10}$ Eastman, Leon Trotsky: Portrait of a Youth, 143.

${ }^{11}$ Deutscher, Prophet Armed, 55-70; Trotsky, My Life, 134-139; Leon Trotsky, My Flight from Siberia (Berlin-Schoeneberg: Publishing House of the Young International, 1923).

${ }^{12}$ L. Glen Seretan, Daniel DeLeon: The Odyssey of an American Marxist (Cambridge and London: Harvard University Press, 1979), 3-8; George Kumler Anderson, The Legend of the Wandering Jew (Providence, Rhode Island: Brown University Press, 1965). See, as well, the poem, "The Wandering Jew," by Voltairine de Cleyre, in Selected Works of Voltarine de Cleyre, ed. Alexander 
Berkman (New York: Mother Earth, 1914), 58-59.

${ }^{13}$ Mayer, "Comrade Shylock," 374-376.

${ }^{14}$ Trotsky, My Life, 334-335; and for an overview of the entire period, Deutscher, Prophet Armed.

${ }^{15}$ Trotsky, My Life, 340-341.

${ }^{16}$ Isaac Deutsher, Stalin (Middlesex: Penguin, 1966), 188-191, 589, 591, 603, 611; Deutsher, "The non-Jewish Jew," 37.

${ }^{17}$ For commentary see Isaac Deutsher, The Prophet Unarmed: Trotsky, 19211929 (New York: Vintage, 1965); Baruch Knei-Paz, The Social and Political Thought of Leon Trotsky (Oxford: Clarendon Press, 1978); the three-volume series, Leon Trotsky, The Challenge of the Left Opposition (New York: Pathfinder, 1975), with Volume I (1923-1925), Volume 2 (1926-1927), and Volume 3 (1928-1929); Trotsky, The New Course (Ann Arbor: University of Michigan Press, 1972); Literature and Revolution (New York: Russell and Russell, no date); Lenin: Notes for a Biographer (New York: Capricorn, 1971); The Permanent Revolution and Results and Prospects (New York: Pathfinder, 1970); The Revolution Betrayed: What is the Soviet Union and Where Is It Going? (New York: Merit, 1965).

${ }^{18}$ Note Deutsher, The Prophet Outcast: Trotsky, 1929-1940 (New York: Vintage, 1963); van Heijenoort, With Trotsky in Exile.

${ }^{19}$ Leon Trotsky, In Defense of Marxism (New York: Pathfinder, 1973).

${ }^{20}$ Trotsky, My Life, 579, 582. 